\title{
Teaching Case: New Product Development And Pre-Launch Plans For Tickets Sales, Inc.
}

Jean M. Lefebvre, Central Connecticut State University, USA Michael Gendron, Central Connecticut State University, USA

\begin{abstract}
Ticket Sales, Inc (TSI) ${ }^{1}$ is a startup business that has received seed funding. TSI is using the seed funding to perform a number of feasibility studies that will enable it to seek first-round venture capital. TSI has already performed a technology feasibility study and a marketing feasibility study, including a 5-year total cost of ownership pro forma budget. Outside consultants were retained to perform the studies. The case presents the Marketing Analysis and Feasibility Study performed by Big Apple Marketing. The TSI management team desires a second opinion concerning the work of Big Apple Marketing ${ }^{1}$ and this case asks that NYC Associates ${ }^{1}$ prepare an assessment of the Marketing Analysis and Feasibility Study in light of documented best practices in new product development.
\end{abstract}

Keywords: New Product Development; Stage-Gate Process; Marketing; Feasibility-Study; Venture-Capital

\section{INTRODUCTION}

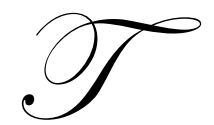

icket Sales, Inc. (TSI) is a startup organization that has obtained seed-funding venture capital to perform various feasibility studies. Essential parts of the Marketing Analysis and Feasibility Study are provided, and assuming assessment of it demonstrates TSI's ability to attain competitive advantage through technology, TSI will seek first-round venture capital to begin operations. TSI intends to operate in the New York City area and its mission is to employ technological solutions to provide easy access to tickets for movies, Broadway shows, and other ticketed events in large metropolitan areas.

TSI has already performed an initial technology assessment and is pleased with it. A marketing feasibility assessment titled the Marketing Analysis and Ticket Sales Forecast Study (referred to as "the study" throughout this case), was performed by Big Apple Marketing and has been reviewed by the TSI management team. Sections of the study appear in Appendix A. The results of this study were incorporated into the overall financial projections done by management. The management team had mixed feelings about the resulting financial projections because they were based on too many unverified assumptions provided by Big Apple Marketing. Some members of the management team felt the financial projections seemed too good to be true. They wondered if Big Apple Marketing had missed some key aspects in their projections and how those projections impacted management's resulting financial estimates. Other members were convinced that market conditions were very attractive to launch TSI and wanted to move immediately before competitors entered the market. All agreed to give a second critical look at essential sections of the Big Apple Marketing study. NYC Associates, a marketing consultancy, was retained to validate the ticket sales projections in the Big Apple Marketing study.

As a recent graduate and new staff member just hired by NYC Associates, you have been charged with the assessment of the Big Apple Marketing study. You have been asked to assess the study in light of documented best practices in new product development. In particular, you are to assess TSI's: 
1. $\quad$ New Product Development (NPD) strategy

2. Opportunity identification

3. Concept development and evaluation

4. Forecasted sales

5. Preliminary financial analysis

6. Overall new product development process, stage-gate by stage-gate

Based on your analyses (1-6 above), you should identify weaknesses, if any, in the study and make suggestions for remedies and improvements. Further, you are to assess the impact of your recommendation on management's financial estimates. Before TSI decides to move to product development, they want NYC Associates' recommendations to continue, kill, or to re-perform initial research for this project. Your goal is to raise expected profits, and lower the risks inherent in the launch of TSI's innovation.

\section{THE E-BUSINESS INNOVATION}

The ticket sales sector of the entertainment industry is a large part of New York City's economy. The market for Broadway theater tickets has been stable for at least several years at around 11 million tickets sold per year, up to 12.3 in the 2006-07 season (Table A2, Appendix A). The market is currently served by several wellestablished competitors, including Ticket Master, TKTS, Ticketron, and the ticket windows in theaters. Despite strong competition, TSI management is convinced that they have a unique and innovative way to offer tickets to theater-goers. The initial technology assessment and marketing study indicate that TSI's solution will provide better, faster, and more efficient services to theater-goers than competitors.

\section{TSI'S BUSINESS MODEL}

TSI will purchase blocks of seats from each venue at a discount and resell them at the face value of the ticket without any service fees. One of TSI's managers puts it this way:

We are able to negotiate significant discounts by bulk purchasing because we take the risk for predicting sales levels for individual events. By committing to purchase blocks of seats, we guarantee our venue partners revenue for those seats, thus giving them an incentive to sell at substantial discounts. TSI's flexible and real-time distribution network will allow us to realize a profit on the margin for each ticket.

\section{TECHNOLOGY SUMMARY}

The technology assessment addressed TSI's major business goals and showed that they could be achieved in a cost-effective manner. In summary, the technology assessment indicates the need for:

\section{Ticket Sales And Operations}

- $\quad$ Connectivity for kiosks located in New York City

- Internet connectivity to support on-line (web) sale of tickets

- $\quad$ An Intranet to support data storage for ticket information sales and purchases

- Main office desktop and remote connectivity for all authorized employees to the GenServe application

\section{Infrastructure}

- Workstations and printers for all staff

- $\quad$ Cost-effective, secure, and reliable Internet connectivity and wiring within TSI's new building

- Servers to support the organizations' needs for intranet and internet email, internal databases, printing, etc.

- $\quad$ Appropriate firewall technology

- $\quad$ VPN access into the TSI network from the Internet for kiosks and remote computers

- Installation and ongoing connectivity to the Internet for the main office and for all kiosks; connectivity to 
the main office must have $95 \%$ uptime reliability

- $\quad$ A backup solution for all servers and desktop PCs

- $\quad$ Uninterruptible power supply support for all infrastructure and servers at the TSI main office

\section{Service Maintenance}

- $\quad$ Onsite hardware service to maintain network and desktops

- $\quad$ Software maintenance for desktops, servers, etc.

\section{Genenco Kiosks, Applications And Back-Office Software}

TSI will provide tickets exclusively through the wide area network of kiosks and via its website, as indicated in the technology assessment. They will procure the web server application, client/server application, back office software, and kiosks from Genenco ${ }^{1}$. Based on the marketing study, TSI will place the kiosks in various public locations throughout New York City (excerpts of that analysis are included in Appendix A.) The web transactions and kiosks will transmit credit card information over the Internet in a secured environment. The web, back office, and client/server (i.e., kiosk/main office) applications are being custom designed and built for TSI, and they will be called GenServe.

The Genenco kiosk client/server and the web application will use a third-party credit card processor to perform credit card validation/verification. The credit card processor will communicate with TSI's bank and merchant account via the Internet. TSI will use an online shopping cart credit card processor for sales through their website. TSI will accept Visa, MasterCard, American Express, Discover, Diner's Club, and debit cards, including credit cards issued by foreign banks.

The kiosks will communicate directly to the TSI home office via a VPN. Genenco will install and service the kiosks, while TSI will provide all connectivity. The kiosks are preloaded with MS-Windows XP, a VPN client and the GenServe client application. The GenServe client application runs as a dedicated application on the kiosks. Main office servers will update kiosk internal databases during normal sales transactions. The updates include changes in venue, show, and seat availability. Consumers purchasing tickets over the web will connect to the GenServe web application through the Internet via their own ISP. GenServe will employ SSL encryption to protect credit card and personal information.

Since this is a retail e-commerce environment and the targeted customers have very high service expectations, kiosk and website response time and reliability are important factors for customer satisfaction and repeat purchases. TSI conducts all of its business electronically and is financially very sensitive to interruptions in its own network and Internet connectivity.

\section{GenServe Hardware Requirements}

The GenServe hardware requirements include the kiosks, the servers, and communication equipment to run the back-office operations. Their total yearly cost estimates appear in Excel sheet "Preliminary Financial Analysis" available at www.gendron.info/TSIcase.

\section{OTHER TSI REQUIREMENTS}

All employees will have Internet access to track theater events at venues within NYC. Therefore, the technology assessment recommends that management be able to track and filter Internet usage by employee. Management also recognizes the need for strong protection from outside intrusion by hackers and viruses. It is worth repeating that the customers TSI will target have very high service expectations. Lack of security would be extremely detrimental to TSI's efforts, especially during the launch campaign when it will entice customers to switch from their usual purchasing methods and buy from its kiosks and Internet site. Therefore, a multi-level approach to security has been designed in the technology assessment. 


\section{Staffing And Building Specs}

TSI will lease a 5-story building with each floor being 7,500 square feet, for a total square footage of $37,500 \mathrm{sq} \mathrm{ft}$. The building will be refurbished to TSI specifications. The Excel sheet "Salaries" provides details on staff requirements, location and costs.

The Excel sheet "Preliminary Financial Analyses" (www.gendron.info/TSIcase), contains all the cost estimates, size of facilities, and personnel details, and assumes that TSI has reached its full level of operations for two reasons: (1) these are the figures investors want to see and (2) technology switching cost from an initially lowvolume infrastructure to a full-volume IT infrastructure is prohibitive. Therefore, a full-volume system will be installed from the start. After initial hiring, staff will be added as sales grow.

\section{Use Of Venture Capital}

As stated above, TSI has used seed-funding venture capital to pay for the necessary feasibility studies. TSI management team has asked NYC Associates, a marketing consultancy, to assess the Marketing Analysis and Feasibility Study before it seeks an additional \$10 million venture capital to begin operation. TSI wants to make sure their presentation to venture capital funding sources is as strong as possible. That is why TSI's management has asked NYC Associates for a review of Big Apple's report.

As a new staff member recently hired by NYC Associates, you have been asked to assess the Marketing Analysis and Feasibility Study in the light of generally accepted best practices in new product development. The document you submit to TSI's management team should have the following structure:

\section{EXECUTIVE SUMMARY}

Assessment of TSI New Product Development process:

1. New Product Development (NPD) strategy

2. Opportunity identification

3. Concept development and evaluation

4. $\quad$ Forecasted sales

5. Preliminary financial analysis

6. Overall new product development process, stage-gate by stage-gate

Based on analyses of 1-6 above, you should identify the weaknesses in the Marketing Analysis and Feasibility Study, if any, and make suggestions for remedies and improvements so as to raise expected profits and lower the risks of the eventual launch of TSI's innovation - purchasing Broadway Theater tickets via kiosks and the Internet.

\section{CONCLUSION}

Recommendations regarding the feasibility of TSI pursuing full development are: recommend a "Go, kill, or recycle" decision.

Faculty interested in using the case should requires the teaching notes from lefebvrej@ccsu.edu and Excel book available at www.gendron.info/TSIcase. 


\section{AUTHOR INFORMATION}

Jean Lefebvre, Professor of Marketing, School of Business, CCSU. Has held several academic leadership positions in the UK, France and the USA; taught Marketing at Université Laval, Québec, Purdue University, Indiana, The Bordeaux School of Management, and the University of Hartford, Connecticut. Business experience as Director of Marketing for a regional engineering consulting firm in Hartford. Education: Syracuse University, NY (Ph.D.), The University of Chicago (MBA), and Paris (ESCP). Research on Family Decision-making and ethnic marketing. Current interests: (1) global new product development, (2) models of managerial performance, (3) educational models of professional schools. Member AMA, PDMA. Fluent in French and Spanish. Email: lefebvrej@ccsu.edu. Corresponding author.

Dr. Michael Gendron has over 30 years of industry and academic experience in information systems. He has held positions such as CIO for a large health maintenance organization, and as a research analyst for a state health department. He holds his Ph.D. in Information Science with specializations in Information Decision Systems and Health Policy and Management from the State University of New York at Albany. E-mail: gendronm@ccsu.edu

\section{REFERENCES}

1. Cooper, R. G. (2...) Product Leadership Creating and Launching Superior News Products, Perseus Books, New York, NY.

2. Crawford, M. and Anthony DiBenedetto (2003) New Products Management, $7^{\text {th }}$ ed., New York: McGrawHill

3. Griffin, A. (1996) "Obtaining Customer Needs for Product Development" The PDMA Handbook of New Product Development, Rosenau et. al., eds., John Wiley \& Sons, p153-56.

4. Haman, G. (1996) "Techniques and tools to generate Breakthrough New Product Ideas," The PDMA Handbook of New Product Development, Rosenau et. al., eds., John Wiley \& Sons, p167-77.

5. Hauser, K. (2000) Who Goes to Broadway? The Demographics of the Audience 1999-2000 Season) The League of American Theatres and Producers, Inc.

6. Hauser, K. (2007) The Demographics of the Broadway Audience 2006-2007, The League of American Theatres and Producers, Inc.

7. Kuczmarski, T., Arthur Middlebrooks and Jeffrey Swaddling (2000) Innovating the Corporation Creating value for customers and Shareholders, Chapter 8 "Problem Orientation," p. 169-201.

8. $\quad$ www.nycvisit.com

9. www.livebroadway.com 
APPENDIX A: MARKETING ANALYSIS AND TICKET SALES FORECAST STUDY

Performed by Big Apple Marketing

\section{SELECTED EXCERPTS}

- $\quad$ The Choice of NYC

- $\quad$ The Market: Broadway Theater Audience Characteristics

- $\quad$ The Determination of Number of Kiosks and Selection of Their Locations

- The Financials and sales forecast (Excel sheet "Preliminary Financial Analyses")

\section{THE CHOICE OF NYC}

Due to its size and rate of growth compared to other US metropolitan areas, TSI management selected NYC as its first target. Broadway shows attract a large and faithful following of NYC residents. Additionally, and despite a lull in the rate of growth of tourism experienced by NYC after 9/11 (see Table A1 below), in 2006 the city received almost 44 million visitors. Most were domestic visitors (36.5 million - up from 30.2 million in 2002) and 7.3 million were international (up from 5.1 million in 2002). These translated into an estimated audience of about 12.3 million (total number of tickets sold) who attended the 1,509 weeks of Broadway productions in 2006 ("1509 weeks" is the sum over all shows of the number of weeks each show operated: www.livebroadway.com).

Table A1: Geographic Origins Of NYC Tourists 1998-2006 (Million Visitors) And Visitor Spending

\begin{tabular}{|c|c|c|c|c|c|c|c|c|c|}
\hline \multirow[t]{2}{*}{ Type of Visitors } & \multicolumn{9}{|c|}{ Year } \\
\hline & 1998 & 1999 & 2000 & 2001 & 2002 & 2003 & 2004 & 2005 & 2006 \\
\hline Total & 33.1 & 36.4 & 36.2 & 35.2 & 35.3 & 37.8 & 39.9 & 42.6 & 43.8 \\
\hline Domestic & 27.1 & 29.8 & 29.4 & 29.5 & 30.2 & 33.03 & 33.8 & 35.8 & 36.5 \\
\hline International & 6.0 & 6.6 & 6.8 & 5.7 & 5.1 & 4.8 & 6.2 & 6.8 & 7.3 \\
\hline $\begin{array}{l}\text { Direct Visitor Spending } \\
\text { (\$ Billion) }\end{array}$ & 14.7 & 15.6 & 17.0 & 15.1 & 14.1 & 18.5 & 21.1 & 22.8 & 24.7 \\
\hline
\end{tabular}

Source: www.nycvisit.com

\section{THE MARKET: BROADWAY THEATER AUDIENCE CHARACTERISTICS}

Size

The yearly total Broadway audience has been stable and increasing slowly over the 2002-2006 period to reach 12.3 million tickets sold in 2006-07 (Table A2).

Table A2: Broadway Audiences (1997-2007)

\begin{tabular}{|c|c|c|c|c|c|c|c|c|c|c|}
\hline & \multicolumn{10}{|c|}{ Year } \\
\hline & $97-98$ & 98-99 & 99-00 & 00-01 & 01-02 & 02-03 & 03-04 & 04-05 & $05-06$ & 06-07 \\
\hline Tickets Sold (million) & 11.5 & 11.7 & 11.4 & 11.9 & 10.9 & 11.4 & 11.6 & 11.5 & 12.0 & 12.31 \\
\hline Musicals & 9.3 & 9.5 & 9.4 & 9.9 & 8.4 & 9.1 & 10.0 & 9.5 & 10.1 & 10.8 \\
\hline Plays & 1.8 & 2.0 & 1.9 & 2.0 & 2.4 & 2.3 & 1.6 & 2.0 & 1.9 & 1.5 \\
\hline Specials & 0.4 & 0.2 & 0.1 & 0.0 & 0.1 & 0.0 & 0.0 & 0.0 & n.a. & n.a. \\
\hline Avg. Paid Admission & $\$ 48$ & $\$ 50$ & $\$ 53$ & $\$ 56$ & $\$ 59$ & $\$ 63$ & $\$ 66$ & $\$ 67$ & $\$ 72$ & $\$ 76$ \\
\hline Musicals & $\$ 51$ & $\$ 52$ & $\$ 55$ & $\$ 58$ & $\$ 62$ & $\$ 67$ & $\$ 68$ & $\$ 68$ & $\$ 73$ & $\$ 78$ \\
\hline Plays & $\$ 39$ & $\$ 42$ & $\$ 44$ & $\$ 48$ & $\$ 48$ & $\$ 49$ & $\$ 55$ & $\$ 61$ & $\$ 67$ & $\$ 64$ \\
\hline Specials & $\$ 41$ & $\# 41$ & $\$ 68$ & $\$ 37$ & $\$ 55$ & $\$ 37$ & $\$ 42$ & $\$ 41$ & n.a. & n.a. \\
\hline Gross (\$ Million) & 552 & 585 & 602 & 666 & 643 & 721 & 771 & 769 & 862 & 939 \\
\hline
\end{tabular}

Source: www.livebroadway.com 


\section{Broadway Demographic Audience Profile Summary}

In 1999-2000 the local residents were the majority of theater-goers. Since then, tourists have become the majority. In 2006-07 tourists purchased approximately $65 \%$ of the 12.3 million tickets sold; domestic U.S. $49.7 \%$ and international tourists $15.5 \%$. The New York City metropolitan area residents accounted for the rest: New York City $16.5 \%$ and NYC suburbs $18.3 \%$. The proportion of foreign visitors has been growing after September 11, 2001. In 2006-07, domestic tourists purchased 6.1 million tickets while international tourists purchased 1.9 million tickets. New Yorkers purchased 2 million and suburbanites 2.3 million tickets.

Theater-goers are mature in age (average age is 41.2 ; the under 18 is a growing segment due to youth and family oriented shows), are mostly women (60\% or more of the audience for the last two decades); as compared to musical attendees, play-goers tend to be older (average age 52) and are more likely to be metro NYC residents. Additionally, women tend to make the decision to see a show for friends and family.

The great majority of the audience are Caucasians (approximately $74.3 \%$, though declining slightly), are quite wealthy (average household income of $\$ 98,900$ in 2006-07), and well-educated (35\% have completed graduate school), and mature in age.

Many in the audience are repeat customers (68\% attended at least two shows in 2006-2007; the average theatergoer attended 4.5 shows), and a small group (5.6\% of theater-goers) attended 15 shows or more and accounted for $37.6 \%$ of ticket sales.

Compared to musical-goers, play-goers are even more educated, wealthy, older, more likely to reside in NYC metro, and attend plays more often ( 9 per season on average).

\section{Frequency Of Attendance}

Broadway theater-goers are repeat customers. On average, they attended 4.5 shows last season, a number that has remained stable over the last several seasons ( $62 \%$ of the audience saw more than one show). The "heavy users" attend 15-25 or more shows per year, buying 37.6\% of all tickets sold in 2006-07 (Table A3). The heavy users tended: (1) to go to more plays (average of 9/year) than to musicals (average of 4/year), (2) to be older (average age of 46 vs. 40 for the light users who attend 1-4 shows annually), and (3) to be local New York metro residents.

Table A3: Frequency Of Attendance (2006-2007)

\begin{tabular}{|c|c|c|c|c|}
\hline $\begin{array}{c}\text { Number of Times } \\
\text { Attended Theater in the } \\
\text { Past Year }\end{array}$ & $\begin{array}{c}\text { Number of Theater- } \\
\text { goers }\end{array}$ & $\begin{array}{c}\text { Number of Theater } \\
\text { Visits }\end{array}$ & $\begin{array}{c}\text { Percent of Theater- } \\
\text { goers }\end{array}$ & $\begin{array}{c}\text { Percent of Theater } \\
\text { Visits }\end{array}$ \\
\hline 1 time & $1.059,696$ & $1,059,696$ & $38.5 \%$ & $8.6 \%$ \\
\hline $2-4$ & $1,018,409$ & $3,055,228$ & $37.0 \%$ & $24.8 \%$ \\
\hline $5-9$ & 379,839 & $2,658,875$ & $13.8 \%$ & $21.6 \%$ \\
\hline $10-14$ & 140,375 & $1,684,504$ & $5.1 \%$ & $13.7 \%$ \\
\hline $15-24$ & 75,900 & $1,517,999$ & $2.8 \%$ & $12.5 \%$ \\
\hline 25 or more & 78,100 & $2,342,999$ & $2.8 \%$ & $18.8 \%$ \\
\hline Total & $2,752,319$ & $12,318,291$ & $100.0 \%$ & $100.0 \%$ \\
\hline
\end{tabular}

*Source: (Hauser, 2007)

\section{Ticket Purchasing Method (Hauser, 2007)}

Overall, telephone charge is decreasing (22\% of theater-goers in 2000 and $11 \%$ in 2007), so is buying at the theater box office (from $24 \%$ to $20 \%$ over the same period), while Internet purchases rose from $7 \%$ to $34 \%$ (Table A4). Older customers have turned to the Internet, only somewhat less so than the average theatergoer. 
- $\quad$ The NYC residents went to the theater box office (29.6\%), purchased on the phone (14.8\%), someone else purchased (3.1\%), "TKTS" booth (9.1\%), group or package deal (4.2\%), Outlet (1.7\%), Internet (35.4\%).

- $\quad$ The NYC Suburbs residents purchased on the phone (14.8\%), went to the box office $(21.1 \%)$, someone else purchased (2.1\%), group or package deal $(9.6 \%)$, “TKTS" booth 9.6\%), Internet $(40.6 \%)$, outlets $(1.3 \%)$.

- $\quad$ The domestic US tourists purchased by phone (9.5\%), at the box office $(15.2 \%)$, someone else purchased $(5.5 \%)$, group package deal (15.6\%), "TKTS" booth (13.7\%), Internet (35.5\%), outlets $(2.2 \%)$.

- $\quad$ The foreign tourists purchased at the box office (23.3\%), "TKTS" booths (26.9\%), someone else purchased (9.8\%), group/Package deal (6.7\%), purchased on the phone (5.9\%), outlet (2.6\%), and Internet (19.2\%).

Table A4: Methods Of Ticket Purchase

\begin{tabular}{|l|c|c|c|c|c|}
\hline Ticket Purchasing Method & Total & NYC & Suburban & $\begin{array}{c}\text { Domestic } \\
\text { Visitors }\end{array}$ & $\begin{array}{c}\text { International } \\
\text { Visitors }\end{array}$ \\
\hline Telephone charge & $10.9 \%$ & $14.8 \%$ & $14.8 \%$ & $9.5 \%$ & $5.9 \%$ \\
\hline Theater box office & 19.7 & 29.6 & 21.1 & 15.2 & 23.3 \\
\hline Internet & 34.2 & 35.4 & 40.6 & 35.5 & 19.2 \\
\hline At "TKTS" booth & 14.0 & 9.1 & 9.6 & 123.7 & 26.9 \\
\hline Broadway Ticket Center & 2.8 & 1.7 & 1.9 & 2.7 & 5.6 \\
\hline Part of group & 9.7 & 4.1 & 7.6 & 13.7 & 4.2 \\
\hline Part of package deal & 1.5 & 0.1 & 0.7 & 1.9 & 2.5 \\
\hline Hotel concierge & 2.6 & 0.6 & 0.2 & 2.9 & 7.0 \\
\hline Broker/scalper & 2.5 & 2.5 & 1.9 & 2.6 & \\
\hline Ticket outlet & 2.0 & 1.7 & 1.3 & & 2.2 \\
\hline
\end{tabular}

*Source: (Hauser, 2007)

\section{Date Of Ticket Purchase}

A great proportion of Broadway show attendees purchase tickets less than a week in advance or on the same day as the performance (more than 40\%). Many more musical than play-goers buy on the same day as the performance ( $28 \%$ vs. $18 \%$ ) (Table A5), but musical-goers are also more likely than play-goers to buy tickets much in advance. International visitors are much more likely to purchase on the day of the show (46\% vs. $23 \%$ for the rest of attendees).

Table A5: Dates Of Ticket Purchase By Musical And Play-Goers

\begin{tabular}{|l|c|c|}
\hline \multicolumn{1}{|c|}{ Date of Ticket Purchase } & Musical & Play \\
\hline Same day as performance & $27.6 \%$ & 25.6 \\
\hline Less than One Week in Advance & 17.2 & 17.0 \\
\hline 1-2 Weeks in Advance & 10.1 & 17.4 \\
\hline 2-4 Weeks in Advance & 12.0 & 14.3 \\
\hline 1-2 Months in Advance & 16.4 & 7.1 \\
\hline 2-4 Months in Advance & 10.4 & 0.5 \\
\hline 4-6 Months in Advance & 4.9 & 0.2 \\
\hline More than 6 Months in Advance & 1.4 & \\
\hline
\end{tabular}

*Source: (Hauser, 2007)

\section{Making The Decision To See A Show}

Among the various influential factors in selecting a show, "personal recommendation" is the strongest and most frequent influence ( $46 \%$ of respondents). This is more so for musicals than for play audiences who are as frequently influenced by "critic's reviews" or "read an article about the play." New Yorkers (34\%) and suburbanites (30\%) were more influenced by reviews than domestic (25\%) or international tourists (24\%). Advertisements come next in frequency of influence (37\%) for musicals and plays. For musicals, TV, billboard and Internet ads are most frequently noted. For plays, newspaper and Internet ads are. 
The profile of the typical decision maker is: "Female, 43.5 years old, attends 5 Broadway shows per year, household income is $\$ 96,900$ and completed college." (Hauser, 2007).

\section{Theatergoing Companions}

Most people attend in the company of one or more others (only $4 \%$ go alone); most often the companions are family and friends (Hauser, 2000).

Incentives To Encourage Theatergoing

When asked about it in a survey, 69\% of respondents said "lower priced tickets" and "Easier Ticket Accessibility" (a distant second at a little more than $20 \%$ of respondents) would be incentives to encourage theatergoing (Hauser, 2000).

\section{Mode Of Transportation To Theater}

Thirty-eight percent of respondents said they went to the theater on foot, $17 \%$ by subway, $12 \%$ by taxi and $9 \%$ by commuter train. The majority of tourists walked to the theater. NYC residents were most likely to take the subway. Suburbanites came by car (49\%) or commuter train (29\%). (Hauser, 2007)

\section{THE DETERMINATION OF NUMBER OF KIOSKS AND SELECTION OF THEIR LOCATIONS}

The total number of kiosks to be installed in the NYC Metropolitan Area was based on revenue, expenses and profitability estimates.

\section{REVENUE ESTIMATES}

\section{Competition}

The three major competitors are TKTS Discount Theater Tickets, Telecharge/Ticketmaster and other Internet ticket sellers, and the theaters ticket windows. Their respective profiles of features and benefits follow:

\section{TKTS}

Sells remaining tickets for the same day, thus no advance reservation possible. Customers must accept seats remaining unsold in the theater. Limited number of Broadway and Off Broadway shows remaining available and probably not the most popular. Discounts vary from $25 \%$ to $50 \%$ of ticket face value. Can be bought from only two locations: Duffy Square and South Street Sea Port. Opening hours of the two TKTS booths are limited. Payment only in cash or by traveler's checks. Often long queues and wait. No additional booking fee. Customers receive actual tickets upon payment.

\section{Telecharge/Ticketmaster}

Customers can buy tickets well in advance of the show, can select either a generic section (Mezzanine, Orchestra, or best available seats) or the actual seat location. Tickets are bought at full value or at a "premium," plus a fee of $\$ 30$ to $\$ 50$ per ticket. Tickets can be purchased on line, at any time, paid for by credit card. No queues or delays. Great availability of Broadway shows. Can print vouchers to be presented at the "Tickets called-in" window at the theater on the day of the performance.

\section{The Theaters' Ticket Windows}

Customers can select their seats, buy in advance of the show, pay the full face value, obtain the actual tickets right away (no queuing again on the night of the show to change the vouchers for tickets). Compared to kiosks and the Internet, customers have to go to the theater from their place of residence or work. Kiosks and the Internet offer similar profiles of beneficial features without having to go far to buy the tickets. On competitive 
advantages of the kiosks and Internet purchase, Big Apple Marketing stated:

We feel that the kiosks offer several advantages compared to buying tickets at theater box office, by telephone, "TKTS" booth, Ticketmaster, and other purchase methods. Kiosks would offer:

1. The ability to select among available seats by viewing the theater floor plan on the screen at the kiosk and on the website, thereby minimizing the risk of unpleasant surprises when you are seated in the theater;

2. Thumbnail summaries of all the shows listed, just touch the screen on the title of the show and the summary appears in a box until the customer touches another title.

3. The ability for customers to retrieve reviews from newspapers, TV and radio by show on the screen.

4. $\quad$ The ability to view a 30 second video of the show on the screen.

5. Immediate delivery of a ticket voucher to be turned in for the actual tickets at the "Tickets called-in" window of the theater.

6. Kiosks would be easily recognizable after the heavy launch communication campaign.

7. Located in many heavily trafficked public places giving easy access to tickets, queuing time at the kiosks would be minimal, and tickets could be purchased earlier than at "TKTS" booths, and thus offer the possibility of buying tickets early for any show and avoid being limited to the remaining shows typically available at the "TKTS" booths.

8. $\quad$ A button on the screen to receive live help.

9. Kiosks allow last minute buying without having to go to one of the two TKTS sites.

and continued:

Ticket buying via the Internet, also offered by TSI, currently accounts for a large fraction of ticket sales, but will continue to grow rapidly. The great majority of theater-goers have access to the Internet at home or at work, except for foreign tourists who have much less access. The convenience of booking via the Internet is even greater than via kiosks. It is a safer and faster transaction, e-tickets are printed immediately as vouchers, one does not even need to walk to a kiosk and can make reservations at any time that is convenient. No additional fee is charged per ticket.

Overall estimates of Broadway yearly theater ticket sales were based on last year's ticket sales by borough assuming no change, a legitimate assumption based on the stability of the number of theater tickets sold over the last four years. The data were obtained from the League of American Theater and Producers Inc. They include the numbers of domestic and foreign tourists who bought tickets after their arrival in NYC.

Forecast of TSI yearly ticket sales were estimated in a sample survey. In a telephone survey, 500 randomly selected residents of metropolitan and suburban NYC, living in areas selected for fitting the socio-demographic profiles of the frequent Broadway theater-goers, were asked by interviewers to indicate how many Broadway theater tickets they intended to buy "over the next year" and express their preferences for various methods of purchasing theater tickets. Respondents were approached with: "This is Joanne from Big Apple Marketing; how would you like a chance to win two free Broadway theater tickets to any show of your choice? ... You simply have to answer four questions." Respondents were then asked how many times they attended Broadway shows during the past year from "none" to " 25 or more times." Respondents were qualified if they answered "one or more times." A high of $36 \%$ of respondents qualified. Respondents were then asked how many Broadway shows they intended to attend during the coming year as well as what methods of purchase they intended to use, including kiosks that were briefly described to the respondents before they stated their method of purchase intentions. Big Apple Marketing, who conducted the survey, stated that the estimated sample percentages were accurate to within plus or minus 4\%, with $95 \%$ confidence. As NYC metro residents do not exhibit the same theatergoing behaviors, another 500 domestic and international visitors were interviewed face-to-face as they returned or left their hotels. The hotels were selected for their proximity to the theater district and proportion of guests visiting from the rest of the USA and abroad. The results appear in Table A6, column 3, "After Kiosks." The "Before Kiosks" figures (Table A6) come from a professional association survey (Hauser, 2007). 
Table A6: Methods Of Purchase Before And After Introduction Of The Kiosks

\begin{tabular}{|c|c|c|}
\hline \multirow[b]{2}{*}{ Ticket Purchasing Method } & \multicolumn{2}{|c|}{ Percent buying } \\
\hline & Before Kiosks* & After Kiosks (Estimates) \\
\hline Telephone Charge & $10.9 \%$ & $8.9 \%$ \\
\hline Theater Box Office & $19.7 \%$ & $16.7 \%$ \\
\hline “TKTS” Booths & $14.0 \%$ & $11.0 \%$ \\
\hline Group/Package Deal & $11.2 \%$ & $11.0 \%$ \\
\hline Broadway Ticket Center & $2.8 \%$ & $2.4 \%$ \\
\hline Internet & $34.2 \%$ & $35.5 \%$ \\
\hline Ticket Broker/Scalper & $2.7 \%$ & $3.0 \%$ \\
\hline Hotel Concierge & $2.5 \%$ & $2.5 \%$ \\
\hline Ticket Outlet & $2.0 \%$ & $2.0 \%$ \\
\hline TSI Internet & $0.00 \%$ & $2.5 \%$ \\
\hline TSI Kiosks & $0.00 \%$ & $4.5 \%$ \\
\hline Total & $100.0 \%$ & $100.0 \%$ \\
\hline
\end{tabular}

*Source: (Hauser, 2007)

On the average, the sampled theater-goers bought 4.4 tickets last year and intended to buy an average 5.21 tickets during the following year.

The data in Table A6 indicate a likely share of method of purchase of $4.5 \%$ for the kiosks, and $2.5 \%$ for TSI Internet sales. A total share of $7 \%$ of method of purchase leads to a sales forecast of 861,700 tickets sold by TSI during the first year after launch $(0.07 \times 12,310,000=861,700)$.

On the one hand, Big Apple Marketing management thought this forecast could be a conservative estimate for several reasons: (1) it does not take into account the likely effects of the launch communication campaign (budgeted at $\$ 14,000,000$ the year of launch). The campaign will be geared to entice theater-goers to switch from telephone buying, buying at the theater itself, TeleCharge/TicketMaster, "TKTS" and start buying from TSI kiosks or TSI Internet website instead. And (2) the launch campaign will target the frequent theater-goers who buy more than the average 4 tickets per year. The typical TSI user could be buying an average of 8 tickets per year, thus doubling the yearly sales level from an anticipated 861,700 to 1,723,400 tickets. That higher forecast would not be expected for the first year after launch, but possibly three to five years hence.

On the other hand, 861,700 tickets could turn out to be an optimistic estimate for several other reasons: (1) respondents expressed intentions to purchase, and intentions are not a reliable predictor of actual behavior. Additionally, (2) respondents were asked to respond about kiosks they have had no experience with (though, New York City residents have had experience buying train and subway tickets from kiosks located in the stations. Only a few TSI kiosks will be located in the major train stations). Respondents produce more accurate answers when talking about their actual experiences than when imagining situations they have not encountered yet. (3) the potential responses from competitors is unknown.

On balance, Big Apple Research selected a conservative estimate of 4\% share of "method of sales" to be achieved in the year of launch, down from the $7 \%$ suggested by the survey results.

NOTE: The Excel spreadsheet "Analysis of Ticket Sales" (www.gendron.info/TSIcase) shows sales of 492,400 tickets in year one, that is, 4\% ("Projected TSI Market Share") of 12.31 million tickets (Table A2). As 20\% ("Expected Unsold Rate") of tickets purchased by TSI will go unsold, TSI must buy more than 492,400 tickets; this number "Expected \# of Tickets to Purchase" is 615,500 (look up the Excel formula) and corresponds to 5\% market share (M.S.). Thus, TSI will buy 615,500 tickets at \$90 (“Average Purchase Cost from Venues"), reflecting an average 40\% discount ("Expected Average TSI Purchase Discount from Venues") on the average face value of $\$ 150$. TSI expects to sell 492,400 at $\$ 150$ ("Average Face Value of a Ticket"), thus making a margin of $\$ 66$ per ticket ("Expected Ticket Margin") and 123,100 tickets are expected to go unsold. Most of the unsold tickets (90\% "Expected Resell Rate") are expected to sell on the secondary market for $45 \%$ of the average face value ("Expected Resell Recoup Ticket Price as \% of Face Value"). 


\section{DETERMINATION OF NUMBER AND LOCATIONS OF KIOSKS}

\section{Determination Of The Number Of Kiosks}

Based on the above TSI sales forecast, Big Apple Marketing estimates that it will take at least 100 kiosks in the NYC metropolitan area and the additional purchases of e-tickets via the Internet, to reach and possibly exceed TSI's sales goal of 492,400 tickets the first year, and increase to 935,253 tickets sold by the end of year five. Big Apple Marketing estimates that by installing a kiosk within 15 minutes walking distance of at least $70 \%$ of theatergoers, TSI sales goals will be achieved.

\section{Allocation Of Kiosks To Boroughs}

Based on past ticket sales by borough, which include the purchases of domestic US and international tourists, the following locations of kiosks are recommended and appear in Table A7.

Table A7: Allocation Of Kiosks To NYC Boroughs

\begin{tabular}{|l|c|}
\hline \multicolumn{1}{|c|}{ Borough } & Number of Kiosks \\
\hline Bronx & 10 \\
\hline Brooklyn & 15 \\
\hline Manhattan & 47 \\
\hline Queens & 15 \\
\hline Staten Island & 12 \\
\hline Total & 99 \\
\hline
\end{tabular}

\section{Location Of Kiosks Within Boroughs}

Three major characteristics were used to identify and rank areas for potential installation of kiosks: density of pedestrian traffic, proportion of pedestrian traffic matching the profile of the frequent theatergoer, and safety. Pedestrian traffic data in public and commercial places, as well as crime statistics, were obtained from the Department of Transportation and the NYC Police Department, which resulted in three categories of sites: "High Potential," "Medium," or "Low." Some "High Potential" sites were to be equipped with several adjacent kiosks, while "Low Potential" sites would receive a single kiosk (Table A8). Many of the kiosks will be located in shopping malls and train stations.

Table A8: Planned Kiosk Locations

\begin{tabular}{|l|c|l|}
\hline \multicolumn{1}{|c|}{ Area } & Number of Kiosks & \multicolumn{1}{c|}{ Location } \\
\hline Bronx & 10 & 3 locations with 2 Kiosks each; 4 separate single kiosks \\
\hline Brooklyn & 15 & All in separate locations \\
\hline Manhattan & 47 & $\begin{array}{l}\text { 5 locations with 3 Kiosks each, 6 locations with 2 Kiosks each; 20 separate single } \\
\text { kiosks }\end{array}$ \\
\hline Queens & 15 & All in separate locations \\
\hline Staten Island & 12 & 5 location with 2 kiosks each; 2 sperate single kiosks \\
\hline Total & 99 & \\
\hline
\end{tabular}

\section{THE FINANCIALS AND SALES FORECAST}

Estimates of operating expenses, estimated revenues and resulting profits for the next five years appear in Excel book available at www.gendron.info/TSIcase. The Excel book has five "sheets": (1) "Preliminary Financial Analyses," (2) "Technology Cost Analysis," (3) "Analysis of Ticket Sales," (4) "Other Assumptions," concerning the bank line of credit, Marketing and other expenses and (5) Employee/Staff estimated costs in "Salaries." The definitions of terms appear in "Excel sheet - Preliminary Financial Analyses" and in the comments boxes attached to cells in the Excel sheets. The five sheets are related: for instance, changing the price of a ticket (in the "Analysis 
of Ticket Sales" sheet) will automatically change the price in the "Preliminary Financial Analyses" sheet. Changing the estimate of employee costs in the "Salaries" sheet will immediately change "Salaries" in the "Preliminary Financial Analyses" sheet, etc. Therefore, the five sheets can easily be used to perform sensitivity analyses by varying the assumptions that underpin TSI's business model and assess the impact of these variations.

The "Preliminary Financial Analyses" sheet shows a middle-of-the-road forecasted five-year expenses and revenues statement. It indicates that TSI business model should prove to be very profitable.

\begin{tabular}{|c|c|}
\hline \multicolumn{2}{|c|}{ Preliminary Financial Analysis: Definition Of Terms } \\
\hline Excel Sheet - Preliminary Financial Analyses & Definitions \\
\hline Connectivity Costs & $\begin{array}{l}\text { Cost of leased lines for connection of the main office and the kiosks to the } \\
\text { Internet, or "External technology infrastructure" }\end{array}$ \\
\hline Technology and Kiosks Lease & Lease cost of internal technology infrastructure at the main office and kiosks \\
\hline Technology Maintenance & Cost of hardware/software maintenance \\
\hline Kiosk (Genenco) Maintenance & Cost of maintenance provided by Genenco and operating supplies \\
\hline Kiosks Space Lease & Cost identified in "Technology Cost Analysis" sheet \\
\hline Salaries & Refer to "Salaries" sheet \\
\hline Office Supplies & Supplies as a percentage of sales at kiosks \& Internet \\
\hline Marketing Expenses & Cost identified in the "Other Assumptions" sheet \\
\hline Miscellaneous Administration & Cost identified in the "Other Assumptions" sheet \\
\hline Office Lease/Utilities & Cost identified in the "Other Assumptions" sheet \\
\hline Cost of Insurance & Cost identified in "Other Assumptions" sheet; see Excel formula in cell E14 \\
\hline Line of Credit & Bank Line of Credit to TSI \\
\hline Cost of Credit Line & $\begin{array}{l}\text { Cost of credit at a percentage of the amount of the line of credit; see "Other } \\
\text { Assumptions" sheet }\end{array}$ \\
\hline Ticket Sales & See "comment" in "Analysis of Ticket Sales" sheet \\
\hline Recoup on Unsold & See formula in "Analysis of Ticket Sales” sheet, cell D21 \\
\hline TOTAL SALES & Total of Sales at Kiosks \& Internet PLUS Recoup on Unsold \\
\hline Cost of Goods Sold-Tickets & Number of tickets purchased TIMES the Average Purchase Cost From Venue. \\
\hline GROSS PROFIT & Total Sales minus Cost of Goods Sold-Tickets \\
\hline Total Expenses & See formula in the Excel sheet \\
\hline Profit Before Taxes & Gross Profit MINUS Total Expenses \\
\hline Corporate Tax & Percentage of Profit Before Taxes \\
\hline NET PROFIT & Profit Before Taxes MINUS Corporate Taxes \\
\hline Cash Balance & $\begin{array}{l}\text { Initially the IPO, then reflective of the impact Cash Disbursements and } \\
\text { Receipts }\end{array}$ \\
\hline Cash Receipts & Total cash received. \\
\hline Cash Disbursements & Total of Cost of Goods Sold PLUS Total Expenses PLUS Corp Tax \\
\hline Ending Cash & Cash Balance PLUS Cash Receipts MINUS Cash Disbursements \\
\hline
\end{tabular}


NOTES 